JEL: C51, C55, F00, F02

\title{
ОПРЕДЕЛЕНИЕ ПРИМЕНИМОСТИ МОДЕЛИ САМУЭЛЬСОНА-ХИКСА В СОВРЕМЕННЫХ ЭКОНОМИЧЕСКИХ УСЛОВИЯХ НА ПРИМЕРЕ АЛЖИРА *
}

\author{
(C) 2021 Трегуб Илона Владимировна \\ доктор экономических наук, профессор департамента математики \\ Финансовый университет при Правительстве Российской Федерации, Россия, Москва \\ E-mail: ilonavl_fa@mail.ru \\ (c) 2021 Байрамуков Локман Хусеинович \\ студент-магистр \\ Финансовый университет при Правительстве Российской Федерации, Россия, Москва \\ E-mail: lokman.bayramukov@gmail.com
}

Предмет/тема. Анализ целесообразности и применимости модели Самуэльсона-Хикса в Алжире за период с 1976 по 2019 год.

Цели/задачи. Анализ проводится в рамках рассмотрения взаимосвязи между валовым внутренним продуктом, инвестициями, потреблением и валовыми государственными расходами.

Методология. Для анализа данных используется методика регрессионного анализа и тест Дарбина-Уотсона, тест Голдфелда-Квандта - для проверки адекватности.

Результаты/Выводы. Исследование проводилось по нескольким направлениям: определение наличия гетероскедастичности; выявление положительных или отрицательных корреляций, а также определение значимости модели и взаимосвязи между статистическими данными. По результатам проведенных анализов, было выявлена не применимость моделей в современных экономических условиях.

Ключевые слова: модель Самуэльсона-Хикса; модель бизнес-цикла; анализ данных; метод наименьших квадратов; инвестиции, регресс.

Алжир, большая, преимущественно мусульманская страна Северной Африки. От побережья Средиземного моря, на котором проживает большинство его жителей, Алжир простирается на юг вглубь Сахары, неприступной пустыни, где были зарегистрированы самые высокие температуры поверхности Земли и которая составляет более четырех пятых площади страны. В стране преобладает Сахара с ее экстремальным климатом.

Теперь поговорим о модели, которую мы используем в этом исследовании; мы будем использовать модель Самуэльсона-Хикса. Следует отметить, что данная модель по своей сути является более совершенным динамическим аналогом кейнсианской модели.

Особенность этой модели также в том, что она применима только для закрытой экономики, но поскольку сейчас мы наблюдаем тесную гло- бализацию и рост отношений между странами, эту модель можно применять только к странам, которые похожи по своему типу и типу. государственное устройство к закрытой экономике. Самуэльсон объединил принцип ускорения и модель множителя. В основе принципа ускорения лежит теория, согласно которой незначительные изменения потребительского спроса могут вызвать значительные изменения инвестиционного спроса. Условия замкнутой экономики страны в текущий период времени описываются переменными: валовым внутренним продуктом $\left(\mathrm{Y}_{\mathrm{t}}\right)$, уровнем потребления $\left(\mathrm{C}_{\mathrm{t}}\right)$, объемом инвестиций $\left(\mathrm{I}_{\mathrm{t}}\right)$ и государственными расходами $\left(\mathrm{G}_{\mathrm{t}}\right)$. Как мы знаем, эконометрика интерпретирует экономические события, используя математический язык.

При переводе приведенных выше утверждений на математический язык мы получаем ис-

\footnotetext{
* Текст статьи приведен на русском языке в сокращенном виде. Полный текст статьи доступен на английском языке на странице 322.
} 
ходную модель Самуэльсона Хикса (формула 1).

Анализ был основан на данных с 1977 по 2019 год, зависимые переменные считаются линейной функцией переменных, указанных в модели. Коэффициенты рассчитываются в соответсвии с формулой 2.

Мы видим очень сильную положительную линейную корреляцию. Если $\mathrm{Y}_{\mathrm{t}-1}$ увеличивается на 1 млрд. LCU, BBП увеличится на 1.1805 млрд. LCU. Если $\mathrm{Y}_{\mathrm{t}-2}$ увеличится на 1 млрд. LCU, ВBП снизится на 0,07923 млрд. LCU. Если госрасходы увеличиваются на 1 млрд. LCU, BBП увеличится на 0,300048 млрд. LCU.

R-квадрат равен 0,993, что означает, что 99,3\% изменения зависимой переменной объясняются независимыми переменными в соответствии с моделью линейной регрессии. Чтобы регрессионный анализ, основанный на обычном методе наименьших квадратов, дал наилучшие возможные результаты, случайная ошибка должна удовлетворять определенным условиям, известным как условия Гаусса-Маркова. Когда все условия выполняются, он обеспечивает наилучшую несмещенную, эффективную и сходящуюся по пределу оценку вектора параметров.

Необходимо выполнить четыре условия, и следует отметить, что даже если одно из них не выполняется, мы можем сказать, что модель не должна использоваться, и либо внести коррективы, либо заменить индикаторы в модели.

Начнем наше исследование с первого условия. Он заключается в том, что математическое ожидание случайной ошибки в каждой модели должно быть равно нулю. Вычислив математическое ожидание в каждой модели, мы получили $\mathrm{E}(\mathrm{u})=0$, это означает, что иногда случайная ошибка будет отрицательной, иногда положительной, но она не должна иметь систематической ошибки. Поскольку мы получили желаемое значение, можно сказать, что условие номер 1 Гаусса-Маркова было выполнено.

Далее нам нужно проверить второе условие, выполнив тест Гольдфельда-Квандта, он нужен для проверки отклонения от гомоскедастичности. Все модели показывают нормальное распределение Е (u). Во всех моделях он равен нулю.

Далее мы должны перейти к третьему условию, в этом условии мы должны проверить отсутствие автокорреляции, мы проверим этот факт, вычислив статистику Дарбина Уотсона остатков е. Рассмотрим этот тест на всех моделях.

Если постоянная Дарвина находится между du и 4-4du, то условие Дарвина-Маркова номер 3 выполняется. Если константа Дарвина находится между 0 и dl, мы имеем положительную корреляцию после корреляции в остатках. Если они находятся между 4-dl и 4, то наши остатки после корреляции отрицательны. В обоих этих случаях третье условие не выполняется. Это сигнал пропущенной переменной. Есть только один подходящий способ: добавить новую переменную, мы должны найти и добавить новую переменную. Мы можем выбрать 4-du или 4-dl, информации о последующей корреляции нет. Мы также можем использовать другой тест.

В результате мы можем посмотреть на состояние каждой модели и принять решение.

Общий вывод по первой модели следующий:

1) Первый GM выполняется;

2) Второй не выполняется;

3) Третий не выполняется.

Итак, для первой модели условия GM не выполняются.

Общий вывод для второй модели следующий:

1) Первый GM выполняется;

2) Второй не выполняется;

3) Третий не выполняется.

$$
\begin{aligned}
& C_{t}=\mathrm{a}_{0}+\mathrm{a}_{1} Y_{t-1}+u_{t} \\
& I_{t}=\mathrm{a}_{2}+\mathrm{a}_{3}\left(Y_{t-1}-Y_{t-2}\right)+v_{t} \\
& G_{t}=\mathrm{a}_{4} G_{t-1}+w_{t} \\
& Y_{t}=\mathrm{C}_{t}+I_{t}+G_{t} \\
& E\left(u_{t}\right)=0, E\left(v_{t}\right)=0, E\left(w_{t}\right)=0 \\
& \sigma\left(u_{t}\right)=\text { const, } \sigma\left(v_{t}\right)=\text { const, } \sigma\left(w_{t}\right)=\text { const } \\
& \left\{\begin{array}{c}
C_{t}=55483.4+0.599 Y_{t-1}+u_{t} \\
I_{t}=3691.4586+0.0069\left(Y_{t-1}-Y_{t-2}\right)+v_{t} \\
G_{t}=333344.89+1.035 G_{t-1}+w_{t} \\
Y_{t}=121324.94+1.18068 * Y_{t-1}+0.0792 * Y_{t-2}+0.300049 G_{t-1}+r_{t}
\end{array}\right.
\end{aligned}
$$


Для второй модели условия GM не выполняются.

Общий вывод по третьей модели следующий:

1) Первый GM выполняется;

2) Второй не выполняется;

3) Третий не выполняется.

Для третьей модели условия GM не выполняются.

И общий вывод по последней модели таков:

1) Первый GM выполняется;

2) Второй не выполняется;

3) Третий не выполняется.

Условия GM для четвертой модели не выполняются.

Регрессионный анализ показал, что эта модель неприменима для Алжира, поскольку не выполняются условия Гаусса-Маркова.

Основным тестом для понимания возможности использования этой модели является тест Дарбина-Уотсона. В исследуемой модели во всех уравнениях присутствует положительная автокорреляция, что означает, что данные коррелированы сами с собой. Более того, тест Голдфилда-Кванта показывает гетероскедастичность. Гетероскедастичность - это систематическое изменение дисперсии остатков по диапазону измеренных значений. Чтобы удовлетворить предположения регрессии и иметь возможность доверять результатам, остатки должны иметь постоянную дисперсию, и в этой модели мы не можем доверять переменным. Переменные опускаются. Значит, наша модель адекватна.

Используя всю информацию, полученную в результате регрессионного анализа, мы можем утверждать, что модель бизнес-цикла Самуэльсона-Хикса не соответствует реалиям Алжира. Этот факт был доказан тестами Дарбина-Уотсона и Голдфилда-Кванта. Первоначальная цель такой системы состояла в том, чтобы объяснить существование бизнес-циклов в экономике, однако в реальных условиях это невозможно. Основное предположение о том, что экономика должна быть закрыта, не может быть применено в реальном мире, оно объясняет, почему модель неприменима.

\section{Библиографический список}

1. Samuelson, P.A. Interactions Between the Multiplier Analysis and the Principle of Acceleration // Review of Economic Statistics. 1939, No. 4 C .: 75-78, http://dx.doi.org/10.2307/1927758.

2. Prangishvili, A.I.; Obgadze, L. T. Mathematical modeling of economic cycles and optimal management of capital investments // Computer Sciences and Tele-communications. 2005 No. 3 (7). P .: 59-61.

3. Tregub I. V.Econometrics. Model of real system. M .: 2016, 164 p.

4. Tregub I. V. Mathematical models of the dynamics of economic systems: monograph - Moscow: RUSAYNS, 2018.$164 \mathrm{p}$.

5. Tregub I. V.Econometric Research. Practical examples. Econometric studies. Practical examples.- Moscow: Lan, $2017.164 \mathrm{p}$.

6. Tregub I. V.Econometrics in English. Tutorial. Moscow: 2017

7. Tregub I. V. Econometric analysis of influence of monetary policy on macroeconomic aggregates in the Indian economy / In: Journal of Physics: Conference Series. 8. Ser. «2018 8th International Conference on Applied Physics and Mathematics, ICAPM 2018» 2018.S. 012025.

8. The World Bank national accounts data [Electronic resource] World Bank Open Data. 2020 URL: https://ata. worldbank.org/, open.

9. The World Bank in Algeria 


\title{
APPLICATION OF THE SAMUELSON-HICKS MODEL IN THE CONDITIONS OF MODERN ECONOMY BY EXAMPLE OF ALGERIA
}

\author{
(C) 2021 Tregub Ilona Vladimirovna \\ Doctor of Economics, Professor of the Department of Mathematics \\ Financial university under the Government of the Russian Federation, Moscow, Russia \\ E-mail: ilonavl_fa@mail.ru

\section{(C) 2021 Bairamukov Lokman KHuseinovich} \\ The master student \\ Financial university under the Government of the Russian Federation, Moscow, Russia \\ E-mail: lokman.bayramukov@gmail.com
}

Subject / topic. In this paper application of Samuelson-Hicks model in the Algeria was analyzed based on a period from 1976 to 2019.

Goals / objectives. The analysis is conducted within the framework of considering the relationship between gross domestic product, investments in non-financial assets, consumption and gross government spending.

Methodology. The regression analysis technique is used for analyzing the data and the Durbin-Watson test, the Goldfeld-Quandt test were made for checking adequacy.

Results / conclusions. The study is carried out in several directions: determination of the presence of heteroskedasticity; identifying positive or negative correlations, as well as determining the significance of the model and the relationship between statistical data. According to the results of the analyzes carried out, it was revealed that the models are not applicable in modern economic conditions.

Keywords: Samuelson-Hicks model; business cycle model; data analysis; least square method; investment, regression.

Algeria, large, predominantly Muslim country of North Africa. From the Mediterranean coast, along which most of its people live, Algeria extends southward deep into the heart of the Sahara, a forbidding desert where the Earth's hottest surface temperatures have been recorded and which constitutes more than four-fifths of the country's area. The Sahara and its extreme climate dominate the country.

Algeria's economy is dominated by its export trade in petroleum and natural gas, commodities that, despite fluctuations in world prices, annually contribute roughly one-third of the country's gross domestic product (GDP). Until 1962 the economy was based largely on agriculture and complemented France's economy. Since then the extraction and production of hydrocarbons have been the most important activity and have facilitated rapid industrialization. The Algerian government instituted a centrally planned economy within a state socialist system in the first two decades after independence, nationalizing major industries and implementing multiyear economic plans. However, since the early 1980s the focus has shifted toward privatization, and Algeria's socialist direction has been modi- fied somewhat. Standards of living have risen to those of an intermediately developed country, but food production has fallen well below the level of self-sufficiency.

Virtually all of Algeria's foreign-exchange earnings are derived from the export of petroleum and natural gas products, both of which are refined domestically at an increasing rate. Other exports include phosphates, vegetables, dates, tobacco, and leather goods. The major imports are capital goods and semifinished products, consisting mostly of industrial equipment and consumer goods, followed closely by foodstuffs. About two-thirds of all trade is with countries of the European Union, and the United States is next in importance.

Now let's talk about the model we use in this study; we will use the Samuelson-Hicks model. It should be noted that this model is, in its essence, a more advanced dynamic analog of the Keynesian model.

The peculiarity of this model is also that it is applicable only for a closed economy, but since we are now seeing a close globalization and an increase in the relationship between countries, this model can only be applied to countries that are similar in their 
type and state structure to a closed economy. Samuelson combined acceleration principle and the multiplier model. In the base of the acceleration principle laid the theory theory that insignificant changes in the consumer's demand can generate significant changes in the investment's demand. The conditions of the closed economy of the country in the current period of time are described by variables: Gross domestic product $\left(\mathrm{Y}_{\mathrm{t}}\right)$, level of consumption $\left(\mathrm{C}_{\mathrm{t}}\right)$, the amount of investment $\left(\mathrm{I}_{\mathrm{t}}\right)$ and government spending $\left(\mathrm{G}_{\mathrm{t}}\right)$.

When creating the Samuelson Hicks model, you need to keep in mind the following points:

1) $G_{t}$ grow at a constant rate of growth;

2) The current $C_{t}$ level is explained by the $Y_{t}$ level in the past period, increasing with it, but at a lower rate;

3) The amount $I_{t}$ is directly proportional to the increase $Y_{t}$ for the previous period;

4) The current value of $Y_{t}$ is the sum of $C_{t}, G_{t}$, $\mathrm{I}_{\mathrm{t}}$.

As we know that econometrics interprets economic events using mathematical language.

When translating the above statements into mathematical language, we get the initial model of Samuelson Hicks:

$$
\left\{\begin{array}{c}
C_{t}=\mathrm{a}_{0}+\mathrm{a}_{1} Y_{t-1}+u_{t} \\
I_{t}=\mathrm{a}_{2}+\mathrm{a}_{3}\left(Y_{t-1}-Y_{t-2}\right)+v_{t} \\
G_{t}=\mathrm{a}_{4} G_{t-1}+w_{t} \\
Y_{t}=\mathrm{C}_{t}+I_{t}+G_{t} \\
E\left(u_{t}\right)=0, E\left(v_{t}\right)=0, E\left(w_{t}\right)=0 \\
\sigma\left(u_{t}\right)=\text { const }, \sigma\left(v_{t}\right)=\text { const }, \sigma\left(w_{t}\right)=\text { const }
\end{array}\right.
$$

Where:

C - Private Consumption expenditure spent by residents or organization which serve households on consumption of goods and services;

I-Investments in Non-Financial Assets - the value of acquisitions of new or existing fixed assets by the business sector less disposals of fixed assets;

G - Government Expenditure - expenditures on goods and services which are used for the satisfaction of needs of individual consumption or collective needs of members of community;

Y - Gross Domestic Product - total amount of money which measure the total production of goods and services on the territory of a by residents and non-residents during the year.

We have obtained an initial model that we will not be able to use in our study, so we should make a reduced model out of it. It should also be noted that a prerequisite for econometric models is the inclusion of a random error in it, so we initially considered the random error.

For analyzing the model, some mathematical transformations were made, the reduced form for prediction looks like:

$$
\left\{\begin{array}{c}
C_{t}=\mathrm{a}_{0}+\mathrm{a}_{1} Y_{t-1}+u_{t} \\
I_{t}=\mathrm{a}_{2}+\mathrm{a}_{3}\left(Y_{t-1}-Y_{t-2}\right)+v_{t} \\
G_{t}=\mathrm{a}_{4} G_{t-1}+w_{t} \\
Y_{t}=\mathrm{a}_{5}+\mathrm{a}_{6} Y_{t-1} \mathrm{a}_{5}+\mathrm{a}_{7} Y_{t-2}+\mathrm{a}_{8} G_{t-1}+r_{t}
\end{array}\right.
$$

After performing some transformations, we got the reduce form of our model and can now use it in our research.

At the beginning of the study, we collected all the necessary data using the World Bank website, we chose GDP, Final consumption expenditure, Foreign direct investment, General government spending. All indicators were taken in current US\$.

The analysis was based on data from 1977 to 2019, the dependent variables are assumed to be a linear function of the variables specified in the model. The coefficients are calculated as follows:

$$
\left\{\begin{array}{c}
C_{t}=55483.4+0.599 Y_{t-1}+u_{t} \\
I_{t}=3691.4586+0.0069\left(Y_{t-1}-Y_{t-2}\right)+v_{t} \\
G_{t}=333344.89+1.035 G_{t-1}+w_{t} \\
Y_{t}=121324.94+1.18068 * Y_{t-1} \\
+0.0792 * Y_{t-2}+0.300049 G_{t-1}+r_{t}
\end{array}\right.
$$

The linear relationship can be seen at the graphs below. See Diagram 1-6.

We will not go into detail on each indicator obtained using regression analysis, since this is not the main purpose of the study. We will consider only the obtained regression equation and make a conclusion from it.

All of these graphs $\mathrm{Y}=\mathrm{f}(\mathrm{Yt}-1), \quad \mathrm{Y}=\mathrm{f}(\mathrm{Yt}-2)$, $\mathrm{Y}=\mathrm{f}(\mathrm{Gt}-1)$ used for the 4 model. We can see very strong positive linear correlation. If Yt-1 increases by $1 \mathrm{bln}$. LCU, the GDP will increase by $1.1805 \mathrm{bln}$. LCU. If Yt- 2 increases by 1 bln LCU, the GDP will decrease by $0.07923 \mathrm{bln}$. LCU. If government spending increases by $1 \mathrm{bln}$. LCU, the GDP will increase by 0.300048 bln. LCU.

R-square is 0,993 which means that $99,3 \%$ in change of dependent variable is explained by independent variables according to linear regression model.

For a regression analysis based on the usual least squares method to produce the best possible 


\section{$C=f(Y t-1)$}

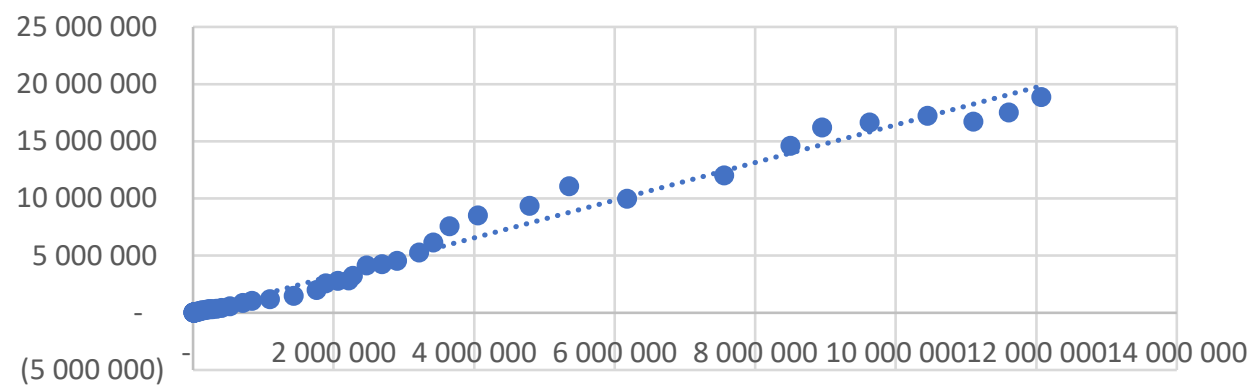

Diagram 1. Scatterplot for values of consumption in current period of time and lagged value of GDP

Conclusion: Strong positive linear correlation. If Y t- 1 increases by 1 bln LCU, the consumption will increase by 0,59 bln LCU

$$
I=f(Y t-1-Y t-2)
$$

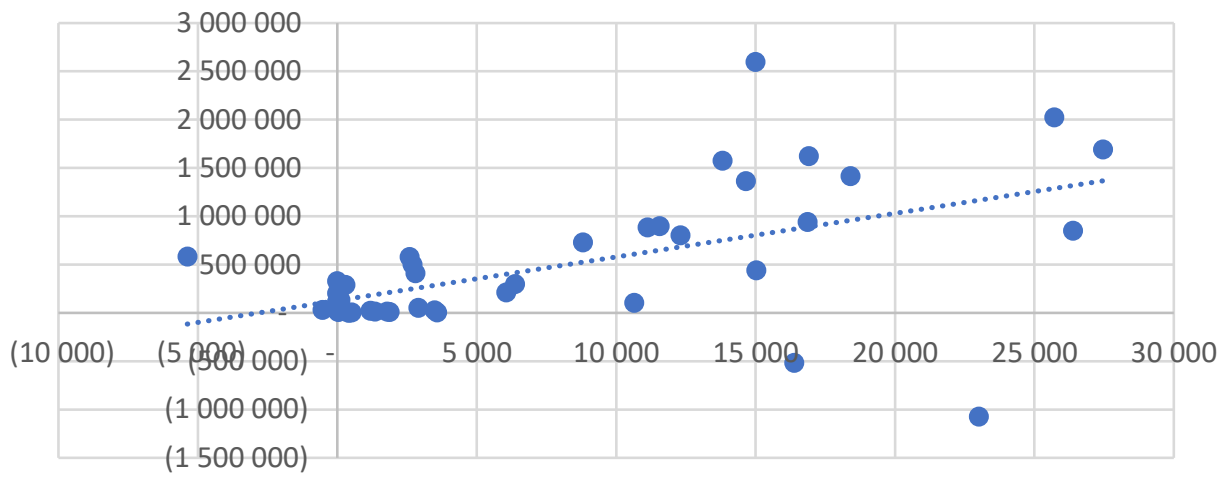

Diagram 2. Scatterplot for values of investments in current period of time and difference between first-lagged and second-lagged values of GDP

Conclusion: Strong enough positive linear correlation. If Y t-1 - Yt-2 increases by 1 bln LCU, the investments will increase by 0,006976 bln LCU

\section{$G=f(G t-1)$}

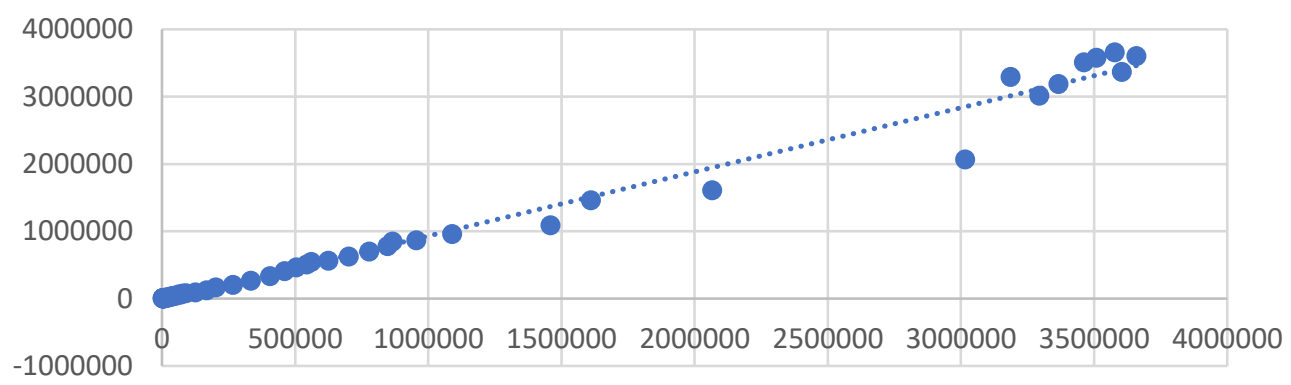

Diagram 3. Scatterplot for values of government spending in current period of time and first-lagged value of them

Conclusion: If Y t-1 - Yt-2 increases by 1 bln LCU, the investments will increase by 1.035 bln LCU 


\section{$Y=f(Y t-1)$}

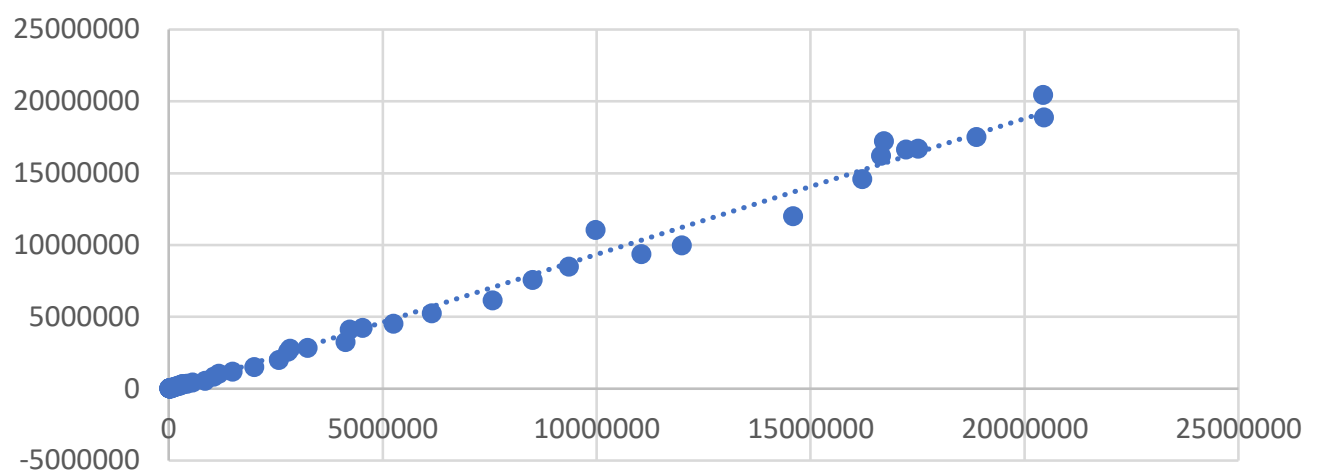

Diagram 4. Scatterplot for values of GDP in current period of time and first-lagged value of GDP

\section{$Y=f(Y t-2)$}

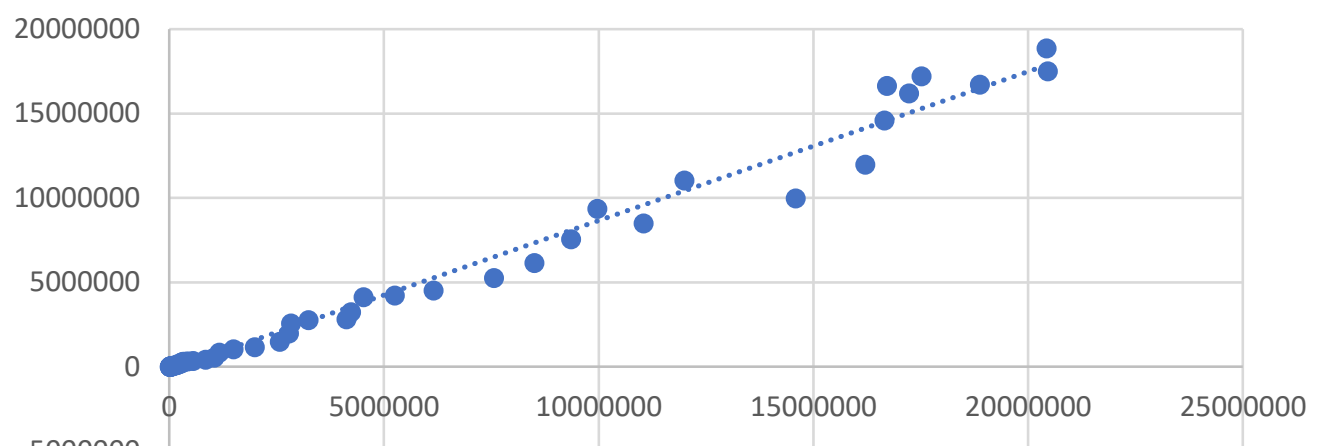

$-5000000$

Diagram 5. Scatterplot for values of GDP in current period of time and second-lagged value of GDP

\section{$Y=f(G t-1)$}

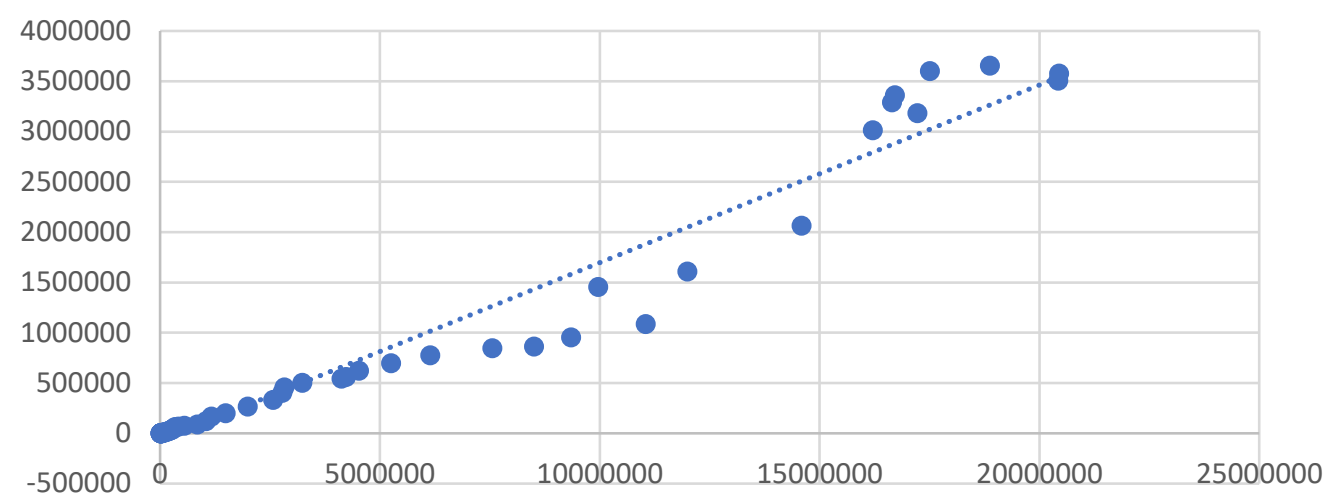

Diagram 6. Scatterplot for values of GDP in current period of time and first-lagged value of government spending 
results, the random error must satisfy certain conditions known as the Gauss-Markov conditions. When all conditions are met, it provides the best unbiased, efficient, and limit-convergent estimate of the parameter vector.

There are four conditions that must be met, and it should be noted that even if one of them is not met, we can say that the model should not be used, and either make adjustments or replace the indicators in the model.

Let's start our research with the first condition. It consists in the fact that the mathematical expectation of a random error in each model should be zero. By calculating the mathematical expectation in each model, we got $\mathrm{E}(\mathrm{u})=0$, this means that sometimes the random error will be negative, sometimes positive, but it should not have a systematic bias. Since we got the desired value, we can say that the condition number 1 of the Gauss Markov was met.
Next, we need to check the second condition by performing the Goldfeld-Quandt test, it is needed to check the deviation from homoscedasticity.

If $\mathrm{GQ}$ and $1 / \mathrm{GQ}$ is less or equals to Fcrit then second GM condition is satisfied. Residuals are homoscedastic and coefficients of model are unbiased, consistent, effective and accurate. If not, this is a signal of omitted variable. In our case, Fcrit, GQ is greater than GQ, this indicates that the second condition of Gauss Markov is not met. In this situation we must find a variable or we may use Weighted least square technic (WLS).

All models show normal distribution of $\mathrm{E}(\mathrm{u})$. It equals to zero in all models.

Next, we must go to the third condition, in this condition we have to check for the absence of autocorrelation, we will check this fact by calculating the Darbin Watson statistics of the residuals of e. Consider this test on all models (See below).

Test for the first model:

$\mathrm{DW}=$

0.553279331

\begin{tabular}{|c|c|c|c|c|c|}
\hline 0 & $\mathrm{~d}_{\mathrm{l}}$ & $\mathrm{d}_{\mathrm{u}}$ & $4-\mathrm{du}$ & $4-\mathrm{dl}$ & 4 \\
\hline 0 & 1.53 & 1.6 & 2.4 & 2.47 & 4 \\
\hline \\
positive autocorrelation & no autocorrelation & \multicolumn{2}{c|}{$\begin{array}{c}\text { negative } \\
\text { autocorrelation }\end{array}$} \\
& no information information
\end{tabular}

Conclusion: Positive autocorrelation in residuals.

Test for the second model:

$D W=1.200148803$

\begin{tabular}{|c|c|c|c|c|c|}
\hline 0 & $\mathrm{~d}_{\mathrm{l}}$ & $\mathrm{d}_{\mathrm{u}}$ & $4-\mathrm{du}$ & $4-\mathrm{dl}$ & 4 \\
\hline \multicolumn{7}{|c|}{1.48} & 1.57 & 2.43 & 2.52 & 4 \\
\hline
\end{tabular}

Conclusion: Positive autocorrelation in residuals.

Test for the third model:

\begin{tabular}{|c|c|c|c|c|c|}
\hline \multicolumn{6}{|c|}{$\mathrm{DW}=$} \\
\hline 0 & $d_{l}$ & $\mathrm{du}_{\mathrm{u}}$ & 4-du & 4- dl & 4 \\
\hline 0 & 1.55 & 1.62 & 2.38 & 2.45 & 4 \\
\hline positive & on & \multirow{2}{*}{\multicolumn{2}{|c|}{ no autocorrelation }} & \multicolumn{2}{|c|}{ negative autocorrelation } \\
\hline \multicolumn{3}{|c|}{ no information } & & no information & \\
\hline
\end{tabular}

Conclusion: Positive autocorrelation in residuals. 
If Darvin constant is between du and 4-4du, then Darvin-Markov condition number 3 is satisfied. There is no after correlation in residuals. Coefficients of the model are unbiased, consistent, efficient, and accurate. If Darvin constants lies between 0 and $\mathrm{dl}$ we have positive after correlation in residuals. If they are between 4 - $\mathrm{dl}$ and 4 , then our residuals are negative after correlated. In both these cases third condition is not satisfied. Coefficients are unbiased, inconsistent, inefficient and not accurate. This is the signal of the omitted variable. There is only one appropriate way: add new variable, we must find and add new variable. We may choose 4-du or 4-dl, there is no info about after correlation. We also may use another test.

As a result, we can look at the conditions of every model and make a decision.

General conclusion for the first model is following:

1) First GM is satisfied;

2) Second is not satisfied;

3) Third in not satisfied.

So, GM conditions are not satisfied for the first model.

General conclusion for the second model is following:

1) First GM is satisfied;

2) Second is not satisfied;

3) Third in not satisfied.

GM conditions are not satisfied for the second model.

General conclusion for the third model is following:

1) First GM is satisfied;

2) Second is not satisfied;

3) Third in not satisfied.

GM conditions are not satisfied for the second model.
And general conclusion for the last model is following:

1) First GM is satisfied;

2) Second is not satisfied;

3) Third in not satisfied.

GM conditions for the fourth model are not satisfied.

However, regression analysis showed that this model is not applicable for the Algeria, because the conditions of Gauss-Markov are not satisfied.

The main test for understanding the feasibility of using this model is the Darbin-Watson test. In the model under study in all equations there is positive autocorrelation, which means that data is correlated with itself. Moreover, Goldfield - Quant test shows heteroscedasticity. Heteroscedasticity is a systematic change in the dispersion of residuals over a range of measured values. In order to satisfy the regression assumptions and be able to trust the results, the residuals must have constant variance, and in this model we cannot trust the variables. Residuals are not homoscedastic, coefficients of the model are biased, inconsistent, ineffective and inaccurate. Variables are omitted. This means that our model is adequate.

Using all the information obtained from the regression analysis, we can argue that the SamuelsonHicks business cycle model does not correspond to the realities of the Algeria. This fact was proved by Durbin-Watson and Goldfield - Quant tests. The original purpose of such a system was to explain the existence of business cycles in an economy, however in the real circumstances it is impossible. The main assumption that the economy should be closed cannot be implied in the real world, it explains why the model is not applicable.

\section{References}

1. Samuelson, P.A.Interactions Between the Multiplier Analysis and the Principle of Acceleration // Review of Economic Statistics. 1939, No. 4 C .: 75-78, http://dx.doi.org/10.2307/1927758.

2. Prangishvili, A.I .; Obgadze, L. T. Mathematical modeling of economic cycles and optimal management of capital investments // Computer Sciences and Tele-communications. 2005 No. 3 (7). P .: 59-61.

3. Tregub I. V. Econometrics. Model of real system. M .: 2016, 164 p.

4. Tregub I. V. Mathematical models of the dynamics of economic systems: monograph - Moscow: RUSAYNS, 2018.-164 p.

5. Tregub I. V.Econometric Research. Practical examples. Econometric studies. Practical examples. - Moscow: Lan, $2017.164 \mathrm{p}$.

6. Tregub I. V. Econometrics in English. Tutorial. Moscow: 2017

7. Tregub I. V.Econometric analysis of influence of monetary policy on macroeconomic aggregates in the Indian economy / In: Journal of Physics: Conference Series. 8. Ser. «2018 8th International Conference on Applied Physics and Mathematics, ICAPM 2018» 2018.S. 012025.

8. The World Bank national accounts data [Electronic resource] World Bank Open Data. 2020 URL: https://data. worldbank.org/, open.

9. The World Bank in Algeria 2020//https://www.worldbank.org/en/country/algeria/overview 